\title{
Gambaran Pembelajaran Keterampilan Menjahit di Balai Latihan Kerja (BLK) Kerinci
}

\author{
Yulsa Nona Hera ${ }^{1^{*}}$ Syuraini $^{1}$ \\ ${ }^{1}$ Jurusan Pendidikan Luar Sekolah, Fakultas Ilmu Pendidikan, Universitas Negeri Padang \\ *e-mail: yulsanonahera@gmail.com \\ (Diterima: 25 Mei 2020, direvisi: 30 Juni 2020, disetujui: 25 Juli 2020)
}

\begin{abstract}
Abstrak
Penelitian ini dilatarbelakangi oleh baiknya hasil belajar warga belajar pada pelatihan menjahit di BLK Kerinci. Hal ini dibuktikan dengan tingginya hasil belajar peserta pelatihan. Keberhasilan ini diduga karena bagusnya pembelajaran yang dilaksanakan oleh instruktur. Penelitian ini bertujuan menggambarkan pelaksanaan pembelajaran keterampilan menjahit dilihat dari metode, media dan evaluasi pembelajaran. Jenis penelitian ini adalah deskriptif kuantitatif dengan populasi 16 orang warga belajar. Sampel penelitian ini adalah keseluruhan dari populasi yang berjumlah 16 orang. Teknik pengumpulan data menggunakan angketdan teknik analisis data mengunakan rumus persentase. Hasil penelitian menunjukkan bahwa (1) pelaksanaan pembelajaran keterampilan menjahit dilihat dari metode yang digunakan diketegorikan baik (2) pelaksanaan pembelajaran keterampilan menjahit dilihat dari media pembelajaran diketegorikan baik (3) pelaksanaan pembelajaran keterampilan menjahit dilihat dari evaluasi diketegorikan baik. Berdasarkan hasil penelitian maka disarankan pelaksanaan pembelajaran warga belajar dari metode, media dan evaluasi dalam mengikuti keterampilan menjahit lebih ditingkatkan lagi agar sesuai dengan tujuan yang yang ingin dicapai.
\end{abstract}

Kata Kunci: Pembelajaran Keterampilan menjahit, Keberhasilan

\begin{abstract}
This research is motivated by the good learning outcomes of citizens learning in sewing training at Kerinci BLK. This is evidenced by the high learning outcomes of trainees. This success is thought to be due to the good learning carried out by the instructor. This study aims to describe the implementation of learning sewing skills seen from the methods, media, and evaluation of learning. This type of research is quantitative descriptive with a population of 16 learning citizens. The sample of this research is the whole of the population of 16 people. Data collection techniques using questionnaires and data analysis techniques using the percentage formula. The results showed that (1) the implementation of sewing skills learning seen from the methods used were categorized well (2) the implementation of sewing skills learning seen from learning media was categorized well (3) the implementation of sewing skills learning seen from the evaluation was categorized well. Based on the results of the study, it is suggested that the implementation of the learning of citizens learning from methods, media, and evaluations in following sewing skills should be further improved to suit the objectives to be achieved.
\end{abstract}

Keywords: Learning,sewing skills, success. 


\section{PENDAHULUAN}

Untuk memperoleh pendidikantidak hanya di sekolah saja (pendidikan formal) akan tetapi juga di luar sekolah (pendidikan Nonformal). Dalam pasal 1 undang-undang nomor 20 tahun 2003 tentang sistem pendidikan nasional dijelaskan bahwa: Pendidikan formal adalah pendidikan yang berstruktur dan berjenjang yang terdiri dari Pendidikan Dasar, Pendidikan Menengah dan Pendidikan Tinggi.

Pelatihan merupakan kegiatan pembelajaran bagi masyarakat yang terencana dan teratur yang bertujuan untuk meningkatkan keterampilan sesuai bakat dan minat. Menurut Michael (dalam Rochayadi, 2014)) menyatakan bahwa istilah latihan adalah proses memperlihatkan tahap dalam melatih bakat dalam penyelesaiaan pekerjaan tertentu [5]. Menurut Sumantri (2000), menyatakan bahwa pelatihan merupakan suatu proses pengetahuan langsung pada alokasi yang lebih singat dalam melaksanakan kebijakan dalam terstruktur dan terorganisasi[11].

Salah satu lembaga pelatihan/kursus adalah UPTD BLK. BLK sendiri merupakan lembaga pelatihan milik negara, yang memberikan pengetahuan dan keterampilan. Jumlah kegiatan pelatihan keterampilan yang diselenggarakan pada setiap tahun 10 kali. Program pelatihan ini semua tidak dipungut biaya. Di dalam UPTD BLK kabupaten Kerinci terdapat berbagai macam jenis pelatihan yang diberikan antara Lain yakni, pelatihan menjahit, Bordir, Otomotif Motor, Otomotif Mobil, Instalasi Listrik, komputer, dan pengelasan. Pelatihan menjahit di BLK yang disesuaikan dengan standar kompetensi kerja Nasional Indonesia (SKKNI) berkapasitas 16 Peserta, dengan lama pelatihan satu bulan, kurikulum yang digunakan yaitu kurikulum berbasis kompetensi, kegiatan ini dilaksanakan 180 jam dengan 25 pertemuan, Media pembelajaran yang digunakan di BLK Kerinci menggunakan modul.

Berdasarkan hasil observasi pada Tangal 15 Juli 2019 yaitu ibuk Okta Neli selaku Instruktur pelatihan menjelaskan 16 orang anggota pelatihan keterampilan menjahit tersebut sangat antusias dan gigih dalam belajar. Mereka selalu mengikuti setiap materi yang diberikan dan selalu berusaha mengikuti proses pelatihan keterampilan menjahit dengan sebaik mungkin, tidak ribut dan tidak ada yang keluar masuk saat kegiatan belajar berlangsung sehingga mendapatkan hasil yang memuaskan. Dilihat dari kehadiran warga belajar cukup tinggi, dapat dilihat dari kehadiran rata-rata di atas $80 \%$. Hal ini dapat diartikan bahwa warga belajar memiliki proses pembelajaran yang baik untuk mengikuti pelatihan menjahit dan dapat mempengaruhi keberhasilan belajar yang diperoleh warga belajar. Dilihat dari keberhasilan warga belajar dalam pelatihan menjahit peserta juga sudah bisa membuka peluang usaha seperti pada tabel 1 . sebagai berikut

\begin{tabular}{|c|c|c|}
\hline No & Jumlah & Usaha Warga Belajar \\
\hline 1. & 3 Orang & Membuka Usaha Jahitan \\
\hline 2. & 4 Orang & $\begin{array}{l}\text { Menerima orderan Jahitan dari tempat usaha } \\
\text { menjahit }\end{array}$ \\
\hline 3. & 9 Orang & $\begin{array}{l}\text { Menerima Jahitan dari keluarga atau anggota } \\
\text { terdekat }\end{array}$ \\
\hline 4. & 1 Orang & $\begin{array}{l}\text { Melanjutkan pelatihan Menjahit ke tingkat } \\
\text { Lanjut. }\end{array}$ \\
\hline
\end{tabular}

Sumber: Pengelola UPTD BLK (Balai Latihan Kerja) Kerinci 
Berdasakan hasil wawancara dengan pengelola UPTD BLK Bapak Suhaidi pada tanggal 15 Juli 2019, diantara warga belajar yang mengikuti pelatihan terdapat 3 orang yang membuka usaha menjahit, 4 orang yang menerima orderan jahitan dari tempat usaha menjahit, 1 orang yang melanjutkan pelatihan menjahit ke tingkat lanjut dan 9 orang yang menerima jahitan dari keluarga atau anggota terdekat. Dari data yang dilihat dapat disimpulkan bahwa BLK telah berhasil dalam Proses pembelajaran. Keberhasilan belajar warga belajar diduga adanya proses pembelajaran yang baik dalam kegiatan pelatihan keterampilan menjahit, warga belajar berusaha datang pada waktu pelatihan keterampilan menjahit, minat belajar peserta pelatihan tinggi, sarana dan prasarana memadai, lingkungan yang mendukung terhadap peserta, instruktur yang menguasai dengan baik di bidang keterampilan menjahit dan metode yang digunakan instruktur bervariasi dan tidak kaku, Berdasarkan fenomena di atas terlihat bahwa semua peserta pelatihan memiliki keikutsertaan yang tinggi pada proses kegiatan pembelajaran keterampilan menjahit.

Menurut Hamdayana (2016), mengatakan Pembelajaran adalah suatu proses belajar yang diharapkan dapat mencapai tujuan atau hasil yang diharapkan[3]. Menurut Sanjaya, (2012) komponen pembelajaran yaitu Metode, Media, dan Evaluasi[7].Oleh karena itu penulis tertarik untuk melakukan penelitian mengenai Gambaran Pembelajaran Keterampilan Menjahit di UPTD BLK Kab. Kerinci.

\section{METODA}

Jenis penelitian ini yaitu penelitian deskriptif kuantitatif. Populasi dari penelitian ini yaitu warga belajar yang mengikuti pelatihan menjahit tahun 2020 sebanyak 16 orang warga belajar. Teknik pengambilan sampel dengan mengunakan sampling jenuh atau sensus. Menurut Sugiyono (2018), sampling jenuh adalah teknik penentuan sampel bila semua anggota populasi digunakan sebagai sampel[10]. Dimana semua anggota populasi dijadikan sampel. Hal ini sering dilakukan bila jumlah populasi relatif kecil, kurang dari 30 orang. Sampel berjumlah 16 orang warga belajar.

Teknik pengumpulan data ialah kuisioner atau angket. Menurut Sugiyiono (2018), menyatakan bahwa angket yaitu teknik pengumpulan data dilaksanakan dengan memberikan seperangkat pertanyaan atau pernyataan tertulis kepada responden untuk dijawabnya[10]. Alat yang digunakan untuk mengumpulkan data ialah daftar pernyataan yang diberikan kepada warga belajar, penyusunan angket menggunakan alternatif jawaban berupa skala likert dengan perhitungan persentase, yaitu menggunakan perhitungan rumus persentase.

$$
\mathrm{P}=\frac{f \times 100 \%}{\mathrm{~N}}
$$

\section{HASIL DAN PEMBAHASAN}

\section{Hasil Penelitian}

Pelaksanaan Pembelajaran Keterampilan Menjahit Di BLK Kerinci Ditinjau dari Aspek Metode Pembelajaran

Data tentang pelaksanaan pembelajaran dilihat dari metode pembelajaran keterampilan menjahit di BLK Kerinci. Terlihat dari histogram 1 berikut ini. 


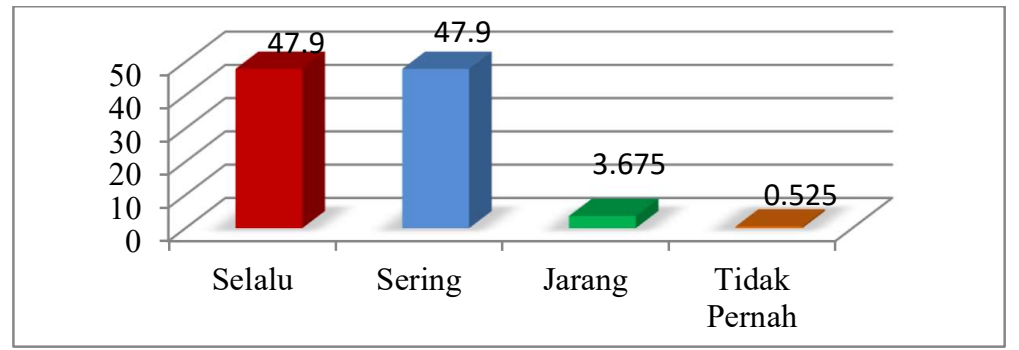

Gambar 1. Histogram pelaksanaan pembelajaran keterampilan menjahit di BLK kerinci ditinjau dari aspek metode pembelajaran

Berdasarkan histogram di atas diketahui pelaksanaan pembelajaran dilihat dari metode pembelajaran keterampilan menjahit di BLK Kerinci, masuk dalam ketegori sangat baik ini terlihat dari persen yang memilih alternatif jawaban Selalu (SL) selalu $47,9 \%$, sering $47,9 \%$, Jarang 3,675\%, dan tidak pernah $0,525 \%$ terhadap gambaran pelaksanaan metode dalam keterampilan menjahit.

Pelaksanaan Pembelajaran Keterampilan Menjahit Di BLK Kerinci Ditinjau dari Aspek Media Pembelajaran

Data tentang pelaksanaan pembelajaran dilihat dari media pembelajaran keterampilan menjahit di BLK. Terlihat dari histogram 2 berikut ini.

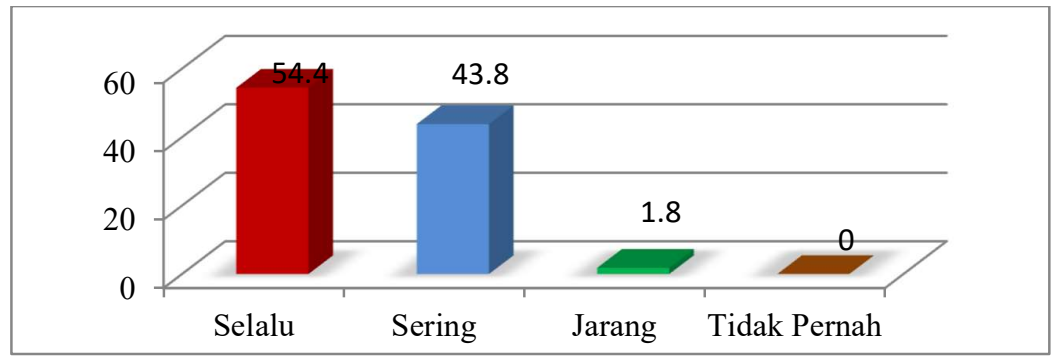

Gambar 2. Histogram pelaksanaan pembelajaran keterampilan menjahit di BLK kerinci ditinjau dari aspek media pembelajaran

Berdasarkan histogram di atas diketahui pelaksanaan pembelajaran dilihat dari media pembelajaran keterampilan menjahit di BLK Kerinci, masuk dalam ketegori sangat baik ini sudah dihitung responden yang memilih alternatif jawaban Selalu (SL) $54,4 \%$, sering $43,4 \%$, Jarang $1,8 \%$, dan tidak pernah $0 \%$ terhadap gambaran pelaksanaan media dalam keterampilan menjahit.

Pelaksanaan Pembelajaran Keterampilan Menjahit Di BLK Kerinci Ditinjau dari Aspek Evaluasi Pembelajaran

Data tentang pelaksanaan pembelajaran dilihat dari evaluasi pembelajaranketerampilan menjahit di BLK Kerinci. Terlihat dari histogram 3 berikut ini. 


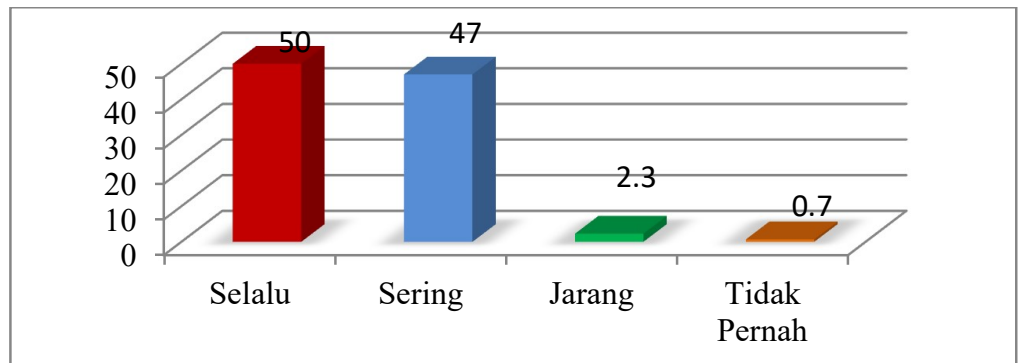

Gambar 3. Histogram pelaksanaan pembelajaran keterampilan menjahit di BLK Kerinci ditinjau dari aspek evaluasi pembelajaran

Berdasarkan histogram di atas diketahui pelaksanaan pembelajaran dilihat dari media pembelajaran keterampilan menjahit di BLK Kerinci, masuk dalam ketegori sangat baik banyak responden yang memilih alternatif jawaban Selalu (SL) 50\%, sering $47 \%$, Jarang 2,3\%, tidak pernah 0,7\% terhadap gambaran pelaksanaan Evaluasi dalam keterampilan menjahit.

Rekapitulasi Gambaran Pembelajaran Keterampilan Menjahit Di Balai Latihan Kerja (BLK) Kerinci

Variabel Gambaran pembelajaran keterampilan menjahit di BLK Kerinci memiliki 3 sub variabel, yaitu 1) Metode pembelajaran dengan 12 item pernyataan, 2) Media Pembelajaran dengan 10 item pernyataan, dan 3) Evaluasi pembelajaran dengan 8 item pernyataan.

Berikut ini hasil rekapitulasi Gambaran pembelajaran keterampilan menjahit di BLK Kerinci

Tabel 2. Rekapitulasi Hasil

\begin{tabular}{llllll}
\hline NO & Sub Variabel & \multicolumn{4}{c}{ Alternatif Jawaban (\%) } \\
& & SL & SR & \multicolumn{1}{c}{ JR } & \multicolumn{1}{c}{ TP } \\
\hline 1 & Metode & $47,9 \%$ & $47,9 \%$ & $3,675 \%$ & $0,525 \%$ \\
2 & Media & $54,4 \%$ & $43,8 \%$ & $1,8 \%$ & $0 \%$ \\
3 & Evaluasi & $50 \%$ & $47 \%$ & $2,3 \%$ & $0,7 \%$ \\
& Jumlah & $\mathbf{1 5 2 , 3 \%}$ & $\mathbf{1 3 8 , 7 \%}$ & $\mathbf{7 , 8 \%}$ & $\mathbf{1 , 2 \%}$ \\
& Rata-rata & $\mathbf{5 0 , 7 7}$ & $\mathbf{4 6 , 2 3 \%}$ & $\mathbf{2 , 6 \%}$ & $\mathbf{0 , 4 1 \%}$ \\
\hline
\end{tabular}

Dari tabel di atas dapat ditarik kesimpulan bahwa Gambaran pembelajaran keterampilan menjahit di BLK Kerinci sudah terlaksana dengan baik. Hal ini dibuktikan dengan banyaknya responden yang memilih altenatif jawaban pernyataan selalu. 47,9\% pada metode pembelajaran, $54,4 \%$ pada Media Pembelajaran, dan $50 \%$ pada Evaluasi pembelajaran. Dapat disimpulkan bahwa persentase pernyataan selalu pada pelaksanaan media pembelajaran keterampilan di BLK Kerinci memiliki nilai paling tinggi yaitu $54,4 \%$.

\section{Pembahasan}

Berdasarkan hasil penelitian, maka bagian ini akan dibahas temuan penelitian tersebut dengan menggunakan teori yang telah dikemukakan pada kajian teori dan juga teori yang relevan. Untuk lebih jelasnya akan dibahas satu per satu dalam pembahasan berikut 
Pelaksanaan Pembelajaran Keterampilan Menjahit Di BLK Kerinci Ditinjau dari Aspek Metode Pembelajaran

Berdasarkan hasil temuan data peneliti tentang pelaksanaan pembelajaran pada aspek metode pembelajaran di BLKKerinci sangat baik. Ini dibuktikan banyaknya warga belajar yang menjawab item pernyataan selalu dan sering. Hal ini disebabkan instruktur telah mengunakan metode yang bervariasi sehingga membuat warga belajar termotivasi dalam mengikuti pelaksanaan pembelajaran keterampilan menjahit, instruktur juga memilih metode mana yang cocok digunakan dalam pelaksanaan pembelajaran.

Djamarah (2010), metode adalah salah satu yang dipergunakan dalam menetapkan target yang telah ditentukan. Di dalam pelatihan keterampilan menjahit Pengunaan metode yang bervariasi[2]. Metode dapat pula membantu sumber belajar (instruktur) dalam pelaksanaan pembelajaran yang tepat sehingga mencapai hasil yang maksimal. Sejalan pendapat Yulidar \& Syuraini (2018), warga belajar memiliki perasaan senang, terus mempelajari metode pembelajaran, tidak terpaksa nyaman dalam belajar dan tidak merasa bosan dengan pembelajaran yang diberikan.[12]

Metode pembelajaran keterampilan memegang peranan penting dalam menyusun pelaksanaan pembelajaran dan metode yang bervariasi dapat menimbukan daya tarik terhadap pelaksanaan pembelajaran yang berlangsung. Kasari \& Syuraini (2019), untuk memunculkan daya tarik pada pelaksanaan pembelajaran instruktur perlu memiliki metode dalam penyampaian materi pembelajaran.[4] Metode merupakan cara seseorang atau instruktur dalam menyampaikan meteri pembelajaran. Sejalan dengan pendapat Sanjaya (2012), metode adalah proses pelaksanaan pembelajaran dalam menerapkan program yang telah di programkan dalam pekerjaan nyata agar bisa tercapai secara menyeluruh dalam penerapan materi pembelajaran.[7]

Jadi dapat disimpulkan bahwa metode pembelajaran keterampilan menjahit adalah sebuah cara yang digunakan instruktur dalam penyajian materi pembelajaran yang diberikan kepada warga belajar supaya terjadi pelaksanaan pembelajaran pada diri warga belajar dalam rangka mencapai tujuan. Metode pembelajaran keterampilan menjahit yang digunakan oleh instruktur selalu penggunaan metodenya bervariasi dan sesuai dengan tujuan pembelajaran sehingga dapat meningkatkan hasil belajar warga belajar.

Pelaksanaan Pembelajaran Keterampilan Menjahit Di BLK Kerinci Ditinjau dari Aspek Media Pembelajaran

Berdasarkan hasil temuan data peneliti tentang pelaksanaan pembelajaran pada aspek media pembelajaran di BLK Kerinci sangat baik. Ini dibuktikan dengan jawaban selalu. Ini instruktur telah menggunakan media pembelajaran yang tepat sesuai dengan materi pembelajaran sehingga dapat meningkatkan motivasi dan pemahaman warga belajar untuk menjahit. Menurut Hamalik (dalam Arsyad, 2014) menyatakan pelaksanaan sistem media pembelajaran mampu menimbulkan hasrat dan kemauan, meningkatkan motivasi, meningkatkan pemahaman, rangsangan aktivitas belajar, serta berdampak pada psikologis warga belajar.[1]

Menurut Rusman (2017), menyatakan media merupakan salah satu bahan yang dipakai dalam menyalurkan materi pada sistem pembelajaran berlangsung, oleh sebab itu media mampu meningkatkan motivasi dan pemahaman warga belajar serta 
meningkatkan interaksi instruktur dengan warga belajar.[6] Sesuai dengan pendapat Sardiman (2008), menyatakan media merupakan bahan untuk menyalurkan sebuah pengetahuan yang dilakukan oleh instruktur.[8]

Menurut Sari \& Syuraini (2019), mengatakan media apabila dipahami secara garis besar adalah manusia, materi atau kejadian yang membangun kondisi yang membuat warga belajar mampu memperoleh pengetahuan, keterampilan dan sikap.[9] Jadi dapat disimpulkan bahwa media pembelajaran merupakan semua alat yang digunakan untuk menunjang pelaksanaan pembelajaran. Dengan pemilihan media yang tepat yang disesuaikan dengan materi pembelajaran sehingga dapat meningkatkan motivasi serta pemahaman warga belajar tentang keterampilan menjahit. Pemilihan media pembelajaran yang tepat dapat meningkatkan pemahaman warga belajar tentang materi yang diajarkan sehingga dapat meningkatkan motivasi warga belajar mengikuti pelatihan menjahit sehingga berdampak terhadap peningkatan hasil belajar yang diinginkan warga belajar.

Pelaksanaan Pembelajaran Keterampilan Menjahit Di BLK Kerinci Ditinjau dari Aspek Evaluasi Pembelajaran

Berdasarkan hasil temuan data peneliti tentang pelaksanaan pembelajaran pada aspek Evaluasi pembelajaran di BLKKerinci sangat baik. Ini dibuktikan dengan jawaban selalu. Ini disebabkan evaluasi yang digunakan instruktur dalam pembelajaran bertujuan untuk mendapatkan data pembuktian yang akan diukur sampai dimana tingkat kemampuan dan keberhasilan warga belajar dalam mencapai tujuan pembelajaran. Menurut Rusman (2017), mengatakan evaluasi pembelajaran merupakan alat/indikator yang bergunakan menilai berbagai hal pada pelaksanaan proses pembelajaran yang terdiri dari menilai proses belajar, dan menilai hasil belajar pembelajaran warga belajar secara utuh.[6]

Menurut menyatakan Evaluasi pembelajaran adalah sebuah proses dalam mengidentifikasi dan mengumpulkan informasi untuk membantu Instruktur dalam mengambil keputusan dan mencari berbagai alternative keputusan dalam sebuah program. Dalam hal menilai hasil belajar warga belajar secara utuh yaitu dengan cara menilai kemajuan atau instruktur melihat perkembangan warga belajar setiap bulan, guna membuat rencana pembelajaan pada periode berikutnya.

Jadi dapat disimpulkan bahwa evaluasi pembelajaran adalah suatu kegiatan pada proses mengidentifikasi dan mengumpulkan informasi oleh instrukutr untuk mengambil keputusan dengan cara menilai proses pembelajaran dan menilai hasil warga belajar secara utuh untuk mendapatkan atau menentukan berhasil atau tidaknya pembelajaranketerampilan menjahit di BLK Kerinci.

\section{SIMPULAN}

Berdasarkan analisis data hasil penelitian dan pembahasan tentang gambaran pembelajaran keterampilan menjahit di BLK Kerinci diperoleh kesimpulan sebagai berikut. Pembelajaran keterampilan menjahit di BLK Kerinci pada aspek metode pembelajaran diketegori baik hal ini terlihat dari metode yang bervariasi, metode yang sesuai dengan tujuan pembelajaran seperti metode ceramah, tanya jawab, dan eksperimen/praktek. 
Pembelajaran keterampilan menjahit di BLK Kerinci pada aspek media pembelajaran diketegori baik hal ini terlihat pembelajaran instruktur mengunakan media yang bisa meningkatkan motivasi warga belajar, peningkatkan pemahaman dan media yang sesuai dengan materi yang diajarkan.

Pembelajan keterampilan menjahit di BLK Kerinci pada aspek evaluasi pembelajaran diketegori baik hal ini terlihat evaluasi pembelajaran yang digunakan instruktur menilai proses belajar warga belajar dan menilai hasil belajar secara utuh.

\section{REFERENSI}

[1] Arsyad, A. (2014). Media Pembelajaran. Jakarta: Grafindo Persada.

[2] Djamarah, Syaiful Bahri \& Aswan Zain. (2010). Strategi Belajar Mengajar. Jakarta: Rineka Cipta.

[3] Hamdayana. (2016). Metodologi Pengajaran. Jakarta: Bumi Aksara.

[4] Kasari, D. Y. M., \& Syuraini, S. (2019). Gambaran Pelaksanaan Pembelajaran Keterampilan Menjahit Pakaian di PKBM. JFACE: Journal of Family, Adult, and Early Childhood Education, (2001). http://doi.org/10.5281/zenodo. 3220261

[5] Rochayadi, I. (2014). Jurnal Empowerment. Upaya Meningkatkan Kompetensi Guru Paud Melalui Pendidikan Dan Pelatihan Guru Di Paud Bougenville Kecamatan Sukajadi Kota Bandung. https://doi.org/10.1017/CBO9781107415324.004

[6] Rusman. (2017). Belajar dan Pembelajaran Berorientasi Standar Proses Pendidikan.Jakarta: Kencana.

[7] Sanjaya, W. (2012). Strategi Pembelajaran Berorientasi Standar Proses Pendidikan.Jakarta: Kencana Prenada Media Grup.

[8] Sardiman, dkk. (2008). Media Pendidikan Pengertian Pengembangan dan Pemanfaatannya. Bandung: Alfabeta.

[9] Sari, P. N., Solfema, S., \& Syuraini, S. (2019). The Difference Participant of Wirid Remaja in Wirid Remaja Activities Using and Not Using Powerpoint Media in Kelurahan Air Tawar Timur. SPEKTRUM: Jurnal Pendidikan Luar Sekolah (PLS), 2(2). http://doi.org/10.24036/spektrumpls.vli2. 9489.

[10] Sugiyono. (2018). metode penelitian pendidikan pendekatan kuantitatif, dan $R \& D$. Bandung: Alfabeta.

[11] Sumantri. (2000). Pelatihan Dan Pengembangan Sumber Daya Manusia. Bandung: Fakultas Psikologi UNPAD.

[12] Yulidar, Y., Syuraini, S., \& Ismaniar, I. (2018). Gambaran Minat Warga Belajar Mengikuti Kegiatan Randai di Sanggar Seni Mustika Minang Duo Kota Pariaman. SPEKTRUM: Jurnal Pendidikan Luar Sekolah (PLS), 1(2). https://doi.org/10.24036/spektrumpls.v1i2.9489 